\title{
Evaluation and Management of Patients with Methomyl Poisoning - A Case Report
}

\author{
Leonardo Pennisi $^{1}$, Anna Lepore ${ }^{1}$, Luigi Santacroce ${ }^{2}$, Roberto Gagliano-Candela ${ }^{3 *}$, Ioannis Alexandros Charitos $^{1}$ \\ ${ }^{1}$ Department of Emergency/Urgency, National Poison Center, Azienda Ospedaliera Universitaria OO.RR. Foggia, Italy; ${ }^{2}$ Ionian \\ Department, Microbiology and Virology Lab., University of Bari, Bari, Italy; ${ }^{3}$ Department of Interdisciplinary Medicine, Section \\ of Forensic Toxicology, University of Bari, Bari, Italy
}

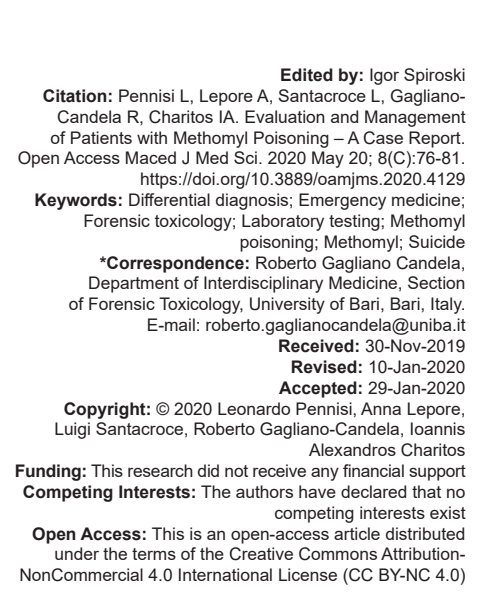

Abstract

The Apulian Poison Centre (PC) of Foggia, Italy, annually manages numerous consultations concerning certain or suspected poisonings from pesticides, starting at the same time a careful activity related to the risk assessment phase. The management of the exposure to pesticides and to other chemicals, and the alerting of the "National center for chemicals, cosmetics and consumer protection" at the Istituto Superiore di Sanità (ISS), actively contributes to the improvement of products quality and safety. Thus, leading to a reduction in the number of intoxications - and therefore of the accesses to the emergency services - allows greater protection for workers, bystanders, residents and consumers. The reported case of methomyl poisoning has been of fundamental importance both from the medical point of view and for the management of the intoxicated patient, both for the risk assessment actions, and for cooperation with the competent authorities, generating discussion points on the regulations in force between PCs and National Competent Authority. It follows that the feedback of intoxication in an emergency can lead to improvements in the management and risk mitigation measures in order to reach a greater protection of human animal, and environmental health. In addition, the regulatory feedback deriving from these reports is an input to the increase product quality improvement (mixtures, labels, packaging, and risk communication) leading to a greater protection of potential exposed subjects. The importance of creating an information and management network that allows the optimization of the flow of information deriving from PCs arises. The actions taken are therefore described, both relating to the management of the emergency, and relating to the subsequent information flow and to the measures for containing the consequent risks.

\section{Background}

The National Poison Centres (PCs) are services of the National Health System dedicated to the treatment, prevention of intoxication and adverse effects due to the exposure to chemical substances (including those considered of abuse) [1]. According to the requirements of the World Health Organization, the PCs are specialized structures in providing the community with information and toxicological advice [2], [3]. In the national Official Journal G.U. No. 65 of March 18, 2017 was issued the Prime Minister Decree of January 12, 2017, which defines new essential levels of assistance (ELA) [4]. In the new legislation, the PCs were inserted (art.36, par.1, letter h) between the areas of activity and hospital assistance (Chapter V, art.36), in this context art.46 shows: The National Health Service guarantees through the PCs specialist consultancy activities for highly complex toxicological problems, to support first aid operative units and other hospital and territorial services, as well as adequate surveillance, vigilance, and alert systems.

The inclusion of the PCs in the ELAs highlighted the importance of the specialist toxicological activities in favor of the emergency urgency system and of all the territorial services, in addition to the consolidated contribution in the field of surveillance, vigilance, and alert.

PCs peculiar characteristics are the management of poisoning, toxicological analysis, surveillance, vigilance and alert, as well as scientific research, and training. In the surveillance, they are actively involved in the development, implementation, and evaluation of measures for the prevention of intoxication or chemical incidents.

They on average represent from $40 \%$ to $61 \%$ of cases of poisonings that a PC annually manages, all in close collaboration with institutions and authorities such as Ministries, Istituto Superiore di Sanità (ISS), AIFA, Regions, Universities, Hospitals, ASL, 118 (equivalent to the 911 phone number of other countries), first aid, public forces, civil protection, and other organizations or private companies (chemical, pharmaceutical chemists, factories in general) and private citizens. In addition, monitoring of adverse drug reactions, warning deriving from contaminated food, and beverages is active, including the sophistication and study of new psychoactive substances and smart drugs. 
The operation of the PCs benefits from the cooperation between the centers themselves, at national and international level, as well as from other institutional bodies involved in prevention and intervention in the event of intoxication. The predominant activity of a PC is the management of acute intoxication. They are linked to prevention, vigilance, and reporting actions applied to various fields. From the environment to food, from drugs to chemicals, while the environment of exposure to these substances varies from the workplace to the domestic one, the latter counts the greater number than cases of exposure/intoxication given the lack of knowledge of the most common safety, product, and labeling rules.

To be recognized overall national territory and to become part of the capillary network of National PCs, nine in Italy, a PC should be able to meet specific quality and confidentiality requirements.

The D.Lgs. of March 14, 2003, No. 653 (implementation of the Directives 1999/45/CE and $2001 / 60 / C E$, subsequently repealed by the European Regulation (EC) n. 1272 of 16 December 2008 (CLP) [5] in Annex XI part $D$ reports the quality and confidentiality criteria to be assured by PCs (Table 1) [6].

These criteria represent the foundation of the PCs and allow the performance on the innumerable work and research activities to which a PC is called.

In addition, a PC to operate as such needs recognition from its own region, of the Ministry of Health and the Ministry of Economic Development.

Furthermore, the definition of PC represents the access key for the consultation of the hazardous preparation archive (HPA) of the ISS [1.S].

In addition to the medical-toxicological activities necessary for continuous clinical research, PCs show a need to link to the evolution and updating of chemical risk assessment and management. It makes essential to include the figure of the specialist (evaluation and management of chemical risk) since this figure would be the link between $\mathrm{PC}$ and national competent authorities and regions in the field of risk assessment [4]. Therefore, the specialist should be able to be included among the regional competent authorities and related technical committees. A PC daily manages various consultations related to exposures, certain or suspected poisonings,

Table 1: The quality and confidentiality criteria of Italian PCs

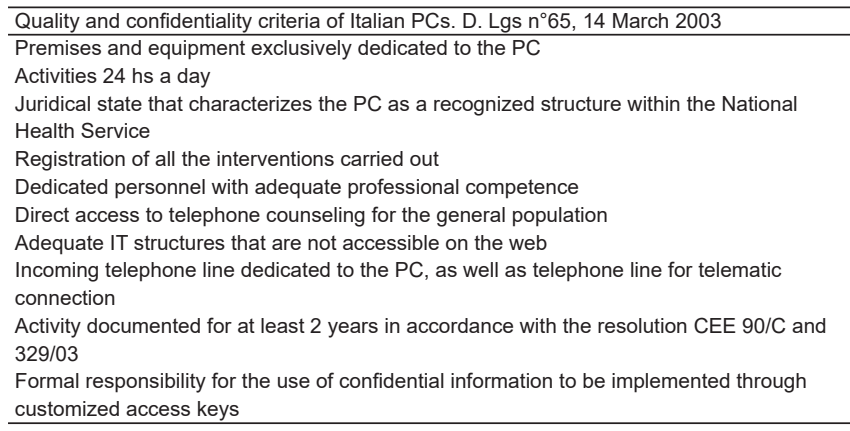

accidents, as well as all the activity related to prevention and vigilance. Even from a single case, it emerges cues for reports, supervisory activities and related assessments on chemicals. The risk management and assessment phase is fundamental for the protection of human, animal, and environmental health, improving the protection of workers and consumers against the risks that derive or may derive from exposure to chemical agents [7], [8], [9], [10], [11], [12].

\section{Case Report}

The health workers of the 118 station of Trinitapoli (BT) contacted the Apulian PC of the Azienda Ospedaliero Universitaria OO.RR. of Foggia, due to the accidental ingestion of an unknown amount of a mixture contained in a dark colored plastic bottle (from subsequent investigations, it has been ascertained that the bottle previously contained mineral water). From a first contact, the 118 operator, following an interview with the company owner, reports to the PC staff that the mixture contained a basic plant protection product of the active ingredient Methomyl (CAS 16752-77-5) [2.S], unspecified quantity. The first phase of data collection refers to the patient's cardio-respiratory arrest: On the spot and in itinerary a resuscitation assistance is provided with respiratory support, cardiac, and continuous monitoring. Upon arrival of the patient in the Emergency Room, the medical staff contacted the PC again and the PC specialist advised that emercency measures and support for airway patency and assisted ventilation if necessary, treatment of the coma and cardiorespiratory arrest and as an antidote treatment atropine and pralidoxime had to be administered empirically. In addition, blood sampling and instrumental continuous monitoring of hepatic-pancreatic-renal function and pseudocholinesterase (PChE) function, in addition to RX-Thorax and RX-Abdomen were prescribed. Subsequently, chest and abdomen CTs were performed without contrast medium. The PC staff setted a follow-up schedule to monitor the patient (Table 2).

\section{Management of the suspected intoxication}

In all cases of suspected or ascertained intoxication by dangerous substances/mixtures and detergents, the Apulian PC of Foggia proceeds to the risk assessment and a careful investigation, so as to be able to better manage the exposure/intoxication/incident and improve the management of the intoxicated patient, deepening the knowledge and activities of supervision and prevention.

The research to individuate the chemical risk was carried out by an initial research on the 
Table 2: The investigations' results

\begin{tabular}{|c|c|}
\hline $\begin{array}{l}\text { Hematochemical tests/ } \\
\text { instrumental examinations }\end{array}$ & Levels/reports \\
\hline AST & $371 \mathrm{U} / \mathrm{L}$ \\
\hline ALT & $390 \mathrm{U} / \mathrm{L}$ \\
\hline LDH & $656 \mathrm{U} / \mathrm{L}$ \\
\hline \multirow[t]{3}{*}{ PChE } & $1^{\text {st }}$ day -4504 (normal range $5320-12920$ ) \\
\hline & $25^{\text {th }}$ day -5290 \\
\hline & $28^{\text {th }}$ day -5412 \\
\hline Pancreatic amylase & $153 \mathrm{U} / \mathrm{L}$ \\
\hline Lipase & $145 \mathrm{U} / \mathrm{L}$ \\
\hline CPK & $303 \mathrm{U/L}$ \\
\hline $\mathrm{RX}$ thorax & Left mediastinal parenchyma consolidation \\
\hline $\begin{array}{l}\text { CT scan of the lungs } \\
\text { (without contrast) }\end{array}$ & $\begin{array}{l}\text { Right lobe parenchymal consolidation areas affecting } \\
\text { the dorsal segment of the upper lobe and most of the }\end{array}$ \\
\hline & $\begin{array}{l}\text { lower lobe. Associated with perifocal and ground-glass } \\
\text { opacities. Right pleural effusion with ground-glass } \\
\text { opacities in lingula pulmonis }\end{array}$ \\
\hline CT scan head (without contrast) & $\begin{array}{l}\text { Diffuse edema with loss of the normal gray-white } \\
\text { differentiation of the two cerebral hemispheres. The } \\
\text { surface of the brain appears smooth }\end{array}$ \\
\hline \multirow[t]{3}{*}{ Endoscopic examination } & 24 January, 2017: Distal esophageal mucosa ulcerated \\
\hline & $\begin{array}{l}\text { pylorus. Nothing against the first and second parts } \\
\text { of the duodenum. Distal erosive esophagitis, diffuse } \\
\text { gastropathy }\end{array}$ \\
\hline & $\begin{array}{l}2 \text { March 2017: Endoscopic aspect compatible with the } \\
\text { evolution of the demarcations of gastric wall lesions }\end{array}$ \\
\hline Exitus & Thirty-third day \\
\hline
\end{tabular}

toxicological and chemical-physical properties of the active substance in the international Micromedex Solution ${ }^{\circledR}$ database, Hazard Management Information section [3.S]. It has emerged that the active substance in question belongs to the carbamate family, less toxic active organophosphorus molecules but with similar clinical effects [13], [14], [15], [16], [17], [18].

They also inhibit the enzyme acetylcholinesterase with a nicotinic symptomatologic manifestation but of short duration and reversible action, with the possibility of specific antidote treatment that involves the use of atropine and pralidoxime, the latter, empirically administered in case of high quantities ingested or in the suspicion of the presence of other substances with nicotinic and muscarinic action (e.g., organophosphorus).

After identifying, the nature of the intrinsic properties of the active substance and taking into account the dangers from the same, we have searched for plant protection products that contain this active ingredient [19], [20], [21].

Thus, making a complete evaluation taking into consideration also other substances present as co-formulants, agronomic antidotes, synergists, etc., that could have toxicological properties and therefore played a role in the accidental intoxication of the worker.

Since the commercial name was not available initially, the investigation was carried out by doing a research on the database of plant health products of the Ministry of Health.

The research was carried out by entering the name of the active substance and as administrative status only authorized products, leaving free the item of parallel import and that of products for ornamental plants and edible plant products, resulting in three plant protection products containing the active substance methomyl.

Since, according to the labels, the mixtures were classified as dangerous in agreement to the EC $1272 / 2008$ (CLP), they were searched also in the HPA of the National Health Institute (formerly ISS), where several dangerous preparations containing the active ingredient methomyl have been found.

They were assessed for the management of intoxication both for the active substance and for the presence of other possible dangerous substances. The evaluation of the safety data sheets (SDS), the compositions reported in the HPA and the evaluation of the current legislation authorizing the active substance methomyl, has produced fundamental data.

In particular, starting from the Directive 2009/115 / EEC, consideration has been given to paragraphs 7 and 10 (Table 3), from which important points of discussion emerged, such as the requirement to incorporate substances with emetic activity in case of intentional or accidental poisoning and to use methomyl products only for professional purposes.

Thus, it remained to check the substance(s) with emetic properties.

The research on the HPA allowed immediately the identification it in the sucrose octaacetate (CAS 126-14-7) and the confirmation was made with the evaluation of the intrinsic properties carried out on the Hazard Management Information section of the international Micromedex Solution ${ }^{\circledR}$ bank. There it was reported that it does not produce significant toxicity but which could be irritating to the eyes and skin and have a mechanical-irritating effect on the mucous membranes.

Then, the staff of the PC had only to understand what the cause of the cardiopulmonary arrest was and how it had arrived at such an important pulmonary and cerebral damage. The collection of this information allowed the chemical risk expert and the PC doctor to arrive to the following conclusion: "The accidental intoxication and therefore the cardiorespiratory arrest were definitely caused by the substance activates methomyl, for which the patient has been treated". Anyway the death has occurred due to causes not related to the active substance but to secondary damages (pulmonary effusion and diffuse bihemispheric edema) probably caused by the induced emesis of the coformulant. The induced or selfinduced emesis, in fact, is always discouraged by all the guidelines of the national and international PCs since the second passage of the toxic could cause further damage.

In this specific case, there was a rise (second step) of the product causing shocking, loss of consciousness and subsequent pulmonary effusion, factors that have led to an important cerebral anoxia producing irreparable and irreversible damage.

The expertise of the chemical risk to carry out a correct and complete evaluation has followed the research 
Table 3: European Commission Directive 2009/115/EC of August 31, 2009 amending Council Directive 91/414/EEC to approve the active substance methomyl

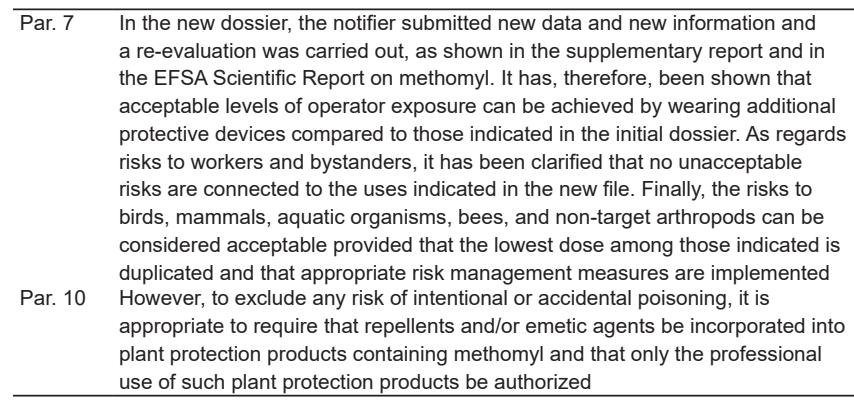

of the two substances (methomyl and the co-formulating agent) on international databases, on the institutional site of European Chemicals Agency (ECHA), on SDS and the labels of several plant protection products.

This to understand if the accident had been caused only by human distraction (misuse) or if there were causes attributable to wrong information on the label or the SDS, packaging or the dilution of the mixture at the preparation site.

\section{Evaluation of substances}

The evaluation began with a study of the risk management section of the international Micromedex Solution $^{\circledR}$ database from which both the chemicalphysical properties and all the information concerning the uses were considered, as in the clinical case management phase, to the workplace exposure limit values, to the lethality values of the test substances, and to all useful information for one.

The study and characterization of the properties of the two test substances have been compared with the classification reported on the institutional site of the European Agency for Chemical Substances (ECHA).

It can be pointed out that only the active ingredient methomyl is classified (acute and chronic toxic to aquatic organisms category (1), and acute toxic category (2) for humans).

In the SDS of the mixture, in section 4, first aid measures; point 4.1, description of first aid measures, it is recommended to induce vomiting in case of ingestion, this procedure is not congruous as previously stated.

Finally, the evaluation of the labels of the plant protection product has brought to light another point of discussion for the competent authorities that the product before use must be previously diluted and that often the residual diluted mixture is stored in unsuitable containers as in the clinical case mentioned above (misuse).

Reporting for National Technical authorities and the Regional and National competent authority

After the closure of the clinical case and its assessment, the chemical risk expert of the PC of
Foggia has notified, through a report, the case to the competent regional and national authorities and to the national technical competent authority.

The purpose was not only of bringing the abovementioned authorities to the attention of the specific case but also to possibly take preventive measures and care to reduce risks and accidents in the workplace.

Thus, implementing what is reported in article 45 of regulation (EC) 1272/2008 (Reg. CLP) paragraph 2 letter b (... to start a statistical analysis to examine any need to improve risk management measures) [22], [23], [24], [25], [26], [27], [28], [29], [30], [31] .

The case was examined by the national technical body that provided a response to the notifying $\mathrm{PC}$, reporting that - until today - it is mandatory, given the dangerousness of the active substance methomyl, to insert in the formulated mixtures of substances with an emetic action, with the sole purpose to remove the toxic in the shortest possible time [32], [33], [34], [35], [36], [37], [38].

Considering the event, there was also a great sensitivity to bring this issue on the European technical tables to be able to re-evaluate the danger of mixtures containing methomyl and the related mandatory prescriptions.

For labeling and preparation and preservation procedures of the mixture, it was definitely agreed that the good phytosanitary practices were not complied with.

\section{Conclusions}

The clinical case of mixture poisoning containing the active ingredient methomyl has been of fundamental importance from the medical point of view for the management of the intoxicated patient, and for the risk assessment, as well as for comparisons with the competent authorities, generating discussion points on regulations and regulations in force between PCs, national technical body, and national authority. This is really important to better define the best procedures for the manipulation of phytosanitary products and, eventually, for possible management of patients which accidentally or voluntary ingest such products.

From this, it follows that the feedback of an intoxication in emergency leads to improvements in management measures and containment of the risk to a greater protection of human health, animals, and the environment and to a significant improvement of products (mixtures, labels, and packaging) and a greater protection of potential exposed.

The importance of creating a network that allows the optimization of the flows of information deriving from PCs arises. 


\section{Authors' Contributions}

All the authors equally contributed.

\section{Acknowledgments}

We thank Dr. Giuseppe Galati and Dr. Giovanni Pepe for their contribution in the management of the patient.

\section{References}

1. Corporate Social Responsibility. Accordo Stato Regioni. Rep att 56/CSR del 28 Febbraio. Corporate Social Responsibility; 2008.

2. World Health Organization. International Programme on Chemical Safety. Guidelines for Poison Control. Geneva: World Health Organization; 1997.

3. Decreto del Presidente del Consiglio dei Ministri 12 Gennaio 2017 Definizione e Aggiornamento dei Livelli Essenziali di Assistenza, di cui All'articolo 1, Comma 7, del Decreto Legislativo 30 Dicembre 1992, n. 502. (17a02015) (G.U. Serie Generale n.65 del 18-03-2017 Suppl. Ordinario No. 15. https:// doi.org/10.2139/ssrn.2157486

4. Gagliano-Candela R. Tossicologia da Pesticidi. Atti Convegno Regionale Agricoltura, Ambiente, Alimentazione, Medicina. Bari: Agricoltura; 1986. p. 99-112.

5. DLgs del 14 Marzo 2003, No. 65; Attuazione Delle Direttive 1999/45/CE e 2001/60/CE Relative Alla Classificazione, All'imballaggio e All'etichettatura dei Preparati Pericolosi; 2003.

6. Regolamento (CE) No. 1272/2008 del Parlamento Europeo e de Consiglio del 16 dicembre 2008; Relativo Alla Classificazione, All'etichettatura e All'imballaggio Delle Sostanze e Delle Miscele che Modifica e Abroga le Direttive 67/548/CEE e 1999/45/CE; 2008. https://doi.org/10.3280/dt2014-010007

7. Direttiva 2009/115/CE della Commissione del 31 Agosto del 2009 che Modifica la Direttiva 91/414/CEE del Consiglio con L'iscrizione Della Sostanza Attiva Methomyl; 2009. https://doi. org/10.3280/dt2014-010007

8. IARC Working Group on the Evaluation of Carcinogenic Risks to Humans. IARC Monographs on the Evaluation of Carcinogenic Risks to Humans: Some Non-heterocyclic Polycyclic Aromatic Hydrocarbons and Some Related Exposures. Lyon, France: International Agency for Research on Cancer; 2010. https://doi. org/10.1007/bf00146899

9. Environmental Protection Agency. EPA Chemical Profile on Methomyl. Washington, DC: Environmental Protection Agency 1985.

10. Lewis RJ. Hawley's Condensed Chemical Dictionary. $12^{\text {th }}$ ed. New York: Van Nostrand Reinhold Company; 1993. p. 752.

11. Gil HW, Hong JR, Song HY, Hong SY. A case of methanol intoxication caused by methomyl pesticide ingestion. Hum Exp Toxicol. 2012;31(12):1299-302. https://doi. org/10.1177/0960327112459532 PMid:23023026

12. Gagliano-Candela R, Uricchio VF, Colucci AP. Toxicological Profiles of Chemicals in Soil. Italy: BARI, Edizioni Giuseppe

\section{Laterza; 2005. p. 999}

13. Gagliano-Candela R, Colucci AP. Banca dati Tossicologica Informatizzata del suolo: Struttura e Finalità. Atti del $33^{\text {rd }}$ Congresso Nazionale SIMLA. Milano: Work Team Sas; 2001. p. 90 .

14. Cagiano R, Bera I, Sabatini R, Flace $P$, Vermesan $D$, Vermesan $\mathrm{H}$, et al. Effects on rat sexual behaviour of acute MDMA (ecstasy) alone or in combination with loud music. Eur Rev Med Pharmacol Sci. 2008;12(5):285-92. PMid: 19024211

15. Reigart JR, Roberts JR. Recognition and Management of Pesticide Poisonings. $5^{\text {th }}$ ed. Washington, DC: United States Environmental Protection Agency; 1999.

16. Liddle JA, Kimbrough RD, Needham LL. A fatal episode of accidental methomyl poisoning. Clin Toxicol. 1979;15(2):159-67. PMid:509881

17. Tsatsakis AM, Bertsias GK, Mammas IN. Acute fatal poisoning by methomyl caused by inhalation and transdermal absorption. Bull Environ Contam Toxicol. 2001;66(4):415-20. https://doi. org/10.1007/s001280021 PMid: 11443300

18. Sofer S, Tal A, Shahak E. Carbamate and organophosphate poisoning in early childhood. Pediatr Emerg Care. 1989;5(4):222 5. https://doi.org/10.1097/00006565-198912000-00005 PMid:2602193

19. Lee DK, Cho NH, Kim OH, Go J, Kim TH, Cha KC, et al. Evaluation of cardiac function using transthoracic echocardiography in patients with myocardial injury secondary to methomyl poisoning. Cardiovasc Toxicol. 2015;15(3):269-75. https://doi.org/10.1007/s12012-014-9295-6 PMid:25410938

20. Clifford NJ, Nies AS. Organophosphate poisoning from wearing a laundered uniform previously contaminated with parathion. JAMA. 1989;262(21):3035-6. https://doi.org/10.1001/ jama.262.21.3035 PMid:2810648

21. Kaplan AM, Sherman H. Toxicity studies with methy $\mathrm{n}-[[($ methylamino $)$ carbonyl]oxy $]$-ethanimidothioate. Toxicol Appl Pharmacol. 1977;40(1):1-17. https://doi. org/10.1016/0041-008x(77)90110-7 PMid:867425

22. Vermesan $D$, Vermesan $H$, Dragulescu SI, Bera I, di Giovanni A, Sabatini R, et al. Secondary pathologic fractures in osteosarcoma: prognosis and evolution. Eur Rev Med Pharmacol Sci. 2009;13(2):71-6.

PMid: 19499840

23. IARC Working Group on the Evaluation of Carcinogenic Risks to Humans. IARC Monographs on the Evaluation of Carcinogenic Risks to Humans: Formaldehyde, 2-Butoxyethanol and 1-tertButoxypropan-2-ol. Lyon, France: International Agency for Research on Cancer; 2006. https://doi.org/10.1093/occmed/ kqr127

24. IARC Working Group on the Evaluation of Carcinogenic Risks to Humans. IARC Monographs on the Evaluation of Carcinogenic Risks to Humans: Household Use of Solid Fuels and Hightemperature Frying. Lyon, France: International Agency for Research on Cancer; 2010a. https://doi.org/10.1007/ bf00146899

25. IARC Working Group on the Evaluation of Carcinogenic Risks to Humans. IARC Monographs on the Evaluation of Carcinogenic Risks to Humans: Smokeless Tobacco and Some Tobacco-specific N-Nitrosamines. Lyon, France: International Agency for Research on Cancer; 2007. https://doi. org/10.1016/0278-6915(89)90054-9

26. IARC. List of All Agents, Mixtures and Exposures Evaluated to 
Date IARC Monographs: Overall Evaluations of Carcinogenicity to Humans, Volumes 1-88, 1972-PRESENT. Lyon, France: World Health Organization, International Agency for Research on Cancer. https://doi.org/10.1002/food.19890330516

27. U.S. Environmental Protection Agency. The List of Extremely Hazardous Substances and their Threshold Planning Quantities (CAS Number Order). Washington, DC: U.S. Environmental Protection Agency; 2010c. Available from: http://www.gpo.gov/ fdsys/pkg/CFR-2010-title40-vol27/pdf/CFR-2010-title40-vol27part355.pdf. [Last accessed on 2011 Jun 17].

28. Gagliano-Candela R, Uricchio VF, Pannacciulli R. Le sostanze Tossiche del Suolo. Proprietà, Analisi, Tossicologia, Sintomatologia ed Ambiente. Italy: Edizioni Giuseppe Laterza Bari; 2000. p. 926.

29. ACGIH. Documentation of the Threshold Limit Values and Biological Exposure Indices. $6^{\text {th }}$ ed. Cincinnati, $\mathrm{OH}: \mathrm{Am}$ Conference of Govt Ind Hyg, Inc.; 1991.

30. Prejbeanu R, Vermesan H, Dragulescu SI, Vermesan D, MotocA Sabatini R, et al. Thromboembolic risk after knee endoprosthesis. Eur Rev Med Pharmacol Sci. 2007;11(5):297-300. PMid:18074938

31. American Conference of Governmental Industrial Hygienists. ACGIH 2010 Threshold Limit Values [TLVs(R) for Chemical Substances and Physical Agents and Biological Exposure Indices $\mathrm{BEIs}(\mathrm{R})]$. Cincinnati, $\mathrm{OH}$ : American Conference of Governmental Industrial Hygienists; 2010. https://doi. org/10.1016/b978-0-12-386454-3.00584-4

32. National Institute for Occupational Safety and Health. NIOSH Pocket Guide to Chemical Hazards, U.S. Department of Health and Human Services. Cincinnati, $\mathrm{OH}$ : Centers for Disease Control and Prevention; 2007. https://doi.org/10.1037/ e371672004-001

33. ERG. Emergency Response Guidebook. A Guidebook for First Responders during the Initial Phase of a Dangerous Goods/Hazardous Materials Incident, U.S. Department of Transportation. Washington, DC: Research and Special Programs Administration; 2004.

34. Inchingolo $F$, Vermesan $D$, Inchingolo $A D$, Malcangi $G$, Santacroce L, Scacco S, et al. Bedsores successfully treated with topical phenytoin. Acta Biomed. 2017;88(1):45-8. PMid:28467333

35. Sax NI, Lewis RJ. Dangerous Properties of Industrial Materials. $7^{\text {th }}$ ed. New York: Van Nostrand Reinhold Company; 1989.

36. Budavari S. The Merck Index. $12^{\text {th }}$ ed. Whitehouse Station, NJ: Merck and Co. Inc.; 1996. p. 1024-5.

37. Piano Regionale di Prevenzione. Approvazione Giunta Regionale Puglia No. 302 del 22/03/2016. Piano Regionale di Prevenzione; 2016.

38. Candela RG, FicarellaA, ColucciAP. Results of the environmental technological risk assessment of an Italian Region (Apulia). Ann lg. 2006;18(6):521-33.

\section{Sitography}

- $\quad$ 1.S. https://preparatipericolosi.iss.it

- $\quad$ 2.S. https://echa.europa.eu/it/home.

- $\quad$ 3.S. http://www.micromedexsolutions.com 